\title{
OBLICZANIE WIĘKSZOŚCI GŁOSÓW WYMAGANEJ DO PODJĘCIA UCHWAEY RADY WIERZYCIELI W POSTĘPOWANIU UPADŁOŚCIOWYM UWAGI NA TLE UCHWAŁY SĄDU NAJWYŻSZEGO Z DNIA 21 KWIETNIA 2016 R., III CZP 3/16
}

\section{Wstęp}

W dniu 21 kwietnia 2016 r. Sąd Najwyższy (SN) podjął uchwałę, w której przedstawiono odpowiedź na dwa pytania prawne dotyczące niezwykle istotnych dla potrzeb praktyki zagadnień obliczania większości głosów w radzie wierzycieli w postępowaniu upadłościowym. Pytanie pierwsze zostało sformułowane następująco:

Czy większość w jakiej rada wierzycieli podejmuje uchwały w postępowaniu upadłościowym na podstawie art. 207 ust. 1 ustawy w dnia 28 lutego 2003 roku - Prawo upadłościowe i naprawcze jest większością zwykłą rozumianą $\mathrm{w}$ ten sposób, że dla skutecznego podjęcia uchwały wystarczające jest, aby liczba głosów „za” przewyższała liczbę głosów „przeciw”; przy jednoczesnym pominięciu głosów „wstrzymujących się", czy też większością bezwzględną rozumianą $\mathrm{w}$ ten sposób że, aby większość została osiągnięta, podczas głosowania liczba głosów „za" musi być większa od głosów „przeciw" i „wstrzymujących się"?

Pytanie drugie zadane przez sąd II instancji miało zaś brzmienie:

Czy większość o jakiej stanowi art. 207 ust. 1 ustawy z dnia 28 lutego 2003 roku należy odnosić do wszystkich członków powołanych przez sędziego

* Dr, Uniwersytet Marii Curie-Skłodowskiej w Lublinie, radca prawny; e-mail: p.telenga@poczta.umcs.lublin.pl, ORCID ID: https:/ / orcid.org/0000-0003-2815-9219.

1 Uchwała Sądu Najwyższego z dnia 21 kwietnia 2016 r., III CZP 3/16, OSNC 2017, nr 3, poz. 29. 
komisarza, czy też do większości faktycznie obecnych na posiedzeniu członków rady wierzycieli?

Na wstępie należy podnieść, że zagadnienia prawne objęte przytoczonymi powyżej pytaniami prawnymi obejmują stan prawny powstały na tle przepisów ustawy Prawo upadłościowe i naprawcze ${ }^{2}$. Z dniem 1 stycznia 2016 r. dokonane zostały zmiany ustawy, w tym zmiana jej nazwy, jednakże stosownie do art. 449 ustawy z dnia 15 maja 2015 r. Prawo restrukturyzacyjne ${ }^{3} \mathrm{w}$ sprawach, w których przed dniem wejścia w życie ustawy wpłynął wniosek o ogłoszenie upadłości, stosuje się przepisy dotychczasowe ${ }^{4}$. Tenże historyczny stan prawny znalazł zastosowanie w przedmiotowej sprawie, jednakże sprawy upadłościowe podlegające - na podstawie powołanego powyżej przepisu - ocenie prawnej na tle tego poprzednio obowiązującego stanu prawnego, nadal toczą się w sądach ${ }^{5}$.

Bezpośrednim impulsem do napisania niniejszej glosy są najnowsze wypowiedzi przedstawicieli doktryny ${ }^{6}$, zdaniem których uchwała SN z dnia 21 kwietnia 2016 r. nie rozwiązała wszystkich wątpliwości dotyczących głosowania w radzie wierzycieli. Jak słusznie zauważono w uzasadnieniu tej uchwały, jedno z zagadnień prawnych przedstawione przez sąd II instancji, stanowi wątpliwość powstałą w doktrynie jeszcze na tle przedwojennego prawa upadłościowego.

2 Ustawa z dnia 28 lutego 2003 r. - Prawo upadłościowe i naprawcze, tekst jednolity: Dz. U. z 2015 r. poz. 233 z późn. zm.; aktualnie: ustawa z dnia 28 lutego 2003 r. - Prawo upadłościowe, tekst jednolity: Dz. U. z 2019 r. poz. 498 z późn. zm. (dalej: u.p.u.n.03).

3 Ustawa z dnia 15 maja 2015 r. - Prawo restrukturyzacyjne, tekst jednolity: DZ. U. z 2019 r. poz. 243 z późn. zm. (dalej: u.p.r.).

4 Zob. jednak art. 448 u.p.r.: „Przepisy o skutkach wszczęcia postępowania co do osoby, majątku i zobowiązań dłużnika lub upadłego stosuje się również do zdarzeń prawnych, które miały miejsce przed dniem wejścia w życie ustawy".

5 Przykładowo według odpowiedzi uzyskanej z Sądu Rejonowego Lublin-Wschód w Lublinie z siedzibą w Świdniku, w tamtejszym sądzie w IX Wydziale Gospodarczym dla spraw upadłościowych i restrukturyzacyjnych w dniu 5 lipca 2019 r. toczyło się 67 postępowań upadłościowych prowadzonych na podstawie przepisów prawa upadłościowego w brzmieniu obowiązującym przed dniem 1 stycznia $2016 \mathrm{r}$.

6 A. Hrycaj, B. Groele, [w:] A. Hrycaj, P. Filipiak (red.), Prawo restrukturyzacyjne. Komentarz, Warszawa 2017, s. 494 i nast. 


\section{Tło sprawy}

Postanowieniem z dnia 10 marca 2015 r. sędzia komisarz powołał radę wierzycieli w postępowaniu upadłościowym likwidacyjnym w składzie: wierzyciel nr 1 (bank), wierzyciel nr 2 (spółka akcyjna), wierzyciel nr 3 (Zakład Ubezpieczeń Społecznych), wierzyciel nr 4 (spółka z o.o.), wierzyciel nr 5 (Skarb Państwa) oraz wierzyciel nr 6 (spółka z o.o.) jako zastępca członka rady wierzycieli. W dniu 20 kwietnia 2015 r. odbyło się posiedzenie rady wierzycieli zwołane przez syndyka masy upadłości. $\mathrm{Na}$ posiedzeniu rady wierzycieli upadłego stawili się członkowie rady wierzycieli reprezentujący wierzyciela $\mathrm{nr} 1, \mathrm{nr} 2$ oraz $\mathrm{nr} 5$, a także osoba $\mathrm{w}$ imieniu wierzyciela $\mathrm{nr} 3$, jednakże nie została ona dopuszczona do udziału w głosowaniu z uwagi na brak stosownego pełnomocnictwa. $\mathrm{Na}$ wniosek wierzyciela $\mathrm{nr} 1$ zaproponowano w porządku obrad m.in. powzięcie uchwały w przedmiocie wyrażenia przez radę wierzycieli zgody na wystąpienie do sędziego komisarza o zmianę warunków przetargu na sprzedaż przedsiębiorstwa. Rada wierzycieli przyjęła uchwałę nr 1. Za uchwałą nr 1 głos „za” oddał tylko jeden wierzyciel (nr 1), zaś pozostali członkowie rady wierzycieli obecni na tym posiedzeniu i dopuszczeni do udziału w głosowaniu, wstrzymali się od głosu.

Postanowieniem z dnia 22 kwietnia 2015 r. sędzia komisarz w postępowaniu upadłościowym, działając z urzędu, uchylił uchwałę rady wierzycieli z dnia 20 kwietnia 2015 r. W uzasadnieniu, jako podstawę uchylenia uchwały wskazał art. 207 ust. 1 zdanie 2 u.p.u.n.03, zgodnie z którym uchwały rady wierzycieli zapadają większością głosów. Zdaniem sędziego komisarza, przepisy dotyczące rady wierzycieli w postępowaniu upadłościowym nie regulują wprost kwestii związanych z wymogami odpowiedniej większości niezbędnej do podjęcia uchwały, w szczególności nie regulują tego, czy „większość” w rozumieniu tego przepisu należy odnosić do wszystkich członków (wówczas niezbędne byłoby uzyskanie zawsze co najmniej trzech głosów za uchwałą w pięcioosobowej radzie), czy też chodzi o większość głosujących (bez konieczności zapewnienia jakiegokolwiek quorum). Powyższe w ocenie sędziego komisarza nie miało jednak znaczenia, gdyż w rozpatrywanej sprawie za uchwałą głosował jedynie jeden z członków na trzech głosujących. Sędzia komisarz wskazał, że odmienna ocena musiałaby wynikać z przyjętego poglądu, iż do ustalania większości konieczne jest, aby głosów „za” było więcej niż głosów „przeciw”, zaś głosy „wstrzymujące” w ogóle nie miałyby znaczenia. 
Zdaniem sędziego komisarza taki pogląd nie jest uzasadniony ani na gruncie wykładani językowej, ani żadnej innej. Pojęcie „większości” za uchwałą w sposób naturalny powinno odnosić się do pozostałej części, która nie jest za uchwałą. Bez znaczenia jest przy tym, czy członek rady nie głosuje, jest przeciw, czy też wstrzymuje się od głosu, gdyż w każdym z tych przypadków nie głosuje za uchwałą. W efekcie sędzia komisarz uznał, że uchwała z dnia 20 kwietnia 2015 r. została przyjęta niewystarczającą liczbą głosów za uchwałą (brak większości z rozumieniu art. 207 ust. 1 u.p.u.n.03).

W dniu 30 kwietnia 2015 r. członek rady wierzycieli (tj. wierzyciel nr 1), wniósł zażalenie na powyższe postanowienie sędziego komisarza dotyczące uchylenia uchwały nr 1 rady wierzycieli z dnia 20 kwietnia 2015 r. i wniósł o uchylenie postanowienia w zaskarżonej części. Rozpoznając to zażalenie, sąd rejonowy przedstawił przytoczone na wstępie zapytania prawne.

\section{Argumentacja Sądu Najwyższego}

Sąd Najwyższy, na oba pytania udzielił tylko jednej odpowiedzi, a mianowicie, że większość głosów wymaganą do podjęcia uchwały rady wierzycieli na podstawie art. 207 ust. 1 u.p.u.n.03 w brzmieniu sprzed nowelizacji dokonanej ustawą z dnia 15 maja 2015 r. - Prawo restrukturyzacyjne określa się w stosunku do pełnego składu rady.

Odpowiedź powyższa zasługuje na aprobatę, aczkolwiek nie rozwiązuje wszystkich możliwych problemów dotyczących głosowania w radzie wierzycieli. Z udzieloną przez SN odpowiedzią łączą się zasadniczo trzy wątki, a mianowicie kwestia wymogu liczby obecnych na posiedzeniu rady wierzycieli, ustalenia większości wymaganej do podjęcia ważnej uchwały w ramach liczby obecnych członków rady i nie mniej ważny, problem uwzględniania w obliczeniu tzw. "głosów wstrzymujących". Wydaje się, że udzielona przez SN odpowiedź - zawarta w sentencji uchwały wraz z osnową jej uzasadnienia - będzie stanowiła istotne dla praktyki wskazówki interpretacyjne dotyczące dwóch pierwszych problemów dotyczących ustalenia ważności uchwały podjętej przez radę wierzycieli. Jednakże przemilczany w podjętej uchwale problem opisany jako trzeci, pozostaje nadal nierozstrzygnięty, co skłania do podjęcia rozważań 
ku rozstrzygnięciu i tej kwestii w niniejszym opracowaniu. Należy mieć jednak na uwadze, że wszystkie te zagadnienia dotyczące ustalenia zasad obliczania głosów - w konsekwencji ustalenia ważności podjętej uchwały rady wierzycieli - pozostają ze sobą w ścisłym związku.

Sąd Najwyższy na poparcie swojego stanowiska, podniósł szereg argumentów odwołując się do funkcjonalnych dyrektyw interpretacji, które w mojej ocenie niewątpliwie zasługują na aprobatę. Po pierwsze, zwrócono uwagę, że w prawie upadłościowym zostały zawarte przepisy określające precyzyjnie zasady obliczania głosów i quorum, co do podejmowania uchwał przez zgromadzenie wierzycieli (art. 199 u.p.u.n.03) oraz przy głosowaniu nad przyjęciem układu (art. 285 u.p.u.n.03), co - przy braku podobnego uregulowania w art. 207 u.p.u.n.03 - prowadzi do wniosku, że w przypadku rady wierzycieli zamiarem ustawodawcy było odniesienie większości głosów do ogólnej liczby członków tej rady. Zdaniem SN, gdyby nie podzielić tego wniosku, ustawodawca wyraźnie określiłby podstawę do ustalania tej większości. Kolejnym argumentem przemawiającym za takim wnioskiem, wg sądu, jest przewidziany przez ustawodawcę celowo nieparzysty skład rady wierzycieli (art. 202 u.p.u.n.03) gwarantujący uzyskanie większości głosów w stosunku do ogólnej liczby członków tego organu. Wskazano także, że zasadniczym zadaniem rady wierzycieli jest reprezentowanie $\mathrm{w}$ postępowaniu upadłościowym interesów ogółu wierzycieli, a nie wyłącznie interesów poszczególnych członków rady.

\section{Ocena prezentowanego problemu prawnego}

Na wstępie zauważmy, że zasadniczy problem prawny, który został podniesiony w zapytaniach prawnych do SN, dotyczy interpretacji treści art. 207 ust. 1 u.p.u.n.03 in fine, który ma następujące brzmienie: „Rada wierzycieli wykonuje czynności przez podjęcie uchwał na posiedzeniach rady. Uchwały rady wierzycieli zapadają większością głosów". Problem ustalenia zasad głosowania, który rysuje się na tle interpretacji powyższego przepisu, ma swoją genezę jeszcze w treści art. $136 \S 1$ pr.upadł. $34^{7}$ o identycznym brzmieniu i niewątpliwie stanowi kontynuację rozbieżności

7 Rozporządzenie Prezydenta Rzeczypospolitej z dnia 24 października 1934 r. - Prawo upadłościowe, Dz. U. z 1934 r. Nr 93, poz. 834 (dalej: pr.upadł.34). 
doktrynalnych, które już wówczas wystąpiły, co zasadnie podkreślono w uzasadnieniu uchwały SN z dnia 21 kwietnia 2016 r.

W zakresie pytania pierwszego postawionego SN, zasadniczo możliwe są dwa stanowiska: pierwsze, że większość głosów, o której mowa w art. 207 ust. 1 u.p.u.n.03, może być większością zwykłą, w której głosy „za” muszą przewyższyć głosy „przeciw”, przy czym głosy „wstrzymujące" są pomijane; drugie, że większość głosów, o której mowa w art. 207 ust. 1 u.p.u.n.03 może być większością zwykłą, w której głosy „za” muszą przewyższyć głosy „przeciw” oraz głosy „wstrzymujące”.

Za pierwszym stanowiskiem, należy podnosić argumentację, że przepis art. 207 ust. 1 u.p.u.n.03 nie reguluje szczegółowo postaci „większości", mimo że w ustawie prawo upadłościowe i naprawcze istnieją przepisy określające sposób liczenia głosów, jak choćby art. 199 czy art. 198 u.p.u.n.03. Zgodnie z treścią art. 199 u.p.u.n.03, jeżeli ustawa nie stanowi inaczej, uchwały zgromadzenia wierzycieli zapadają bez względu na liczbę obecnych, większością głosów wierzycieli. Z kolei według art. 198 u.p.u.n.03: „wierzyciela, który wstrzymał się od głosu uważa się za nieuczestniczącego w głosowaniu". Zdaniem sądu za przyjęciem drugiego stanowiska - zgodnie, z którym przy obliczaniu większości, głosy "wstrzymujące się" mają znaczenie i należy je uwzględniać przy liczeniu głosów - przemawia główny cel, dla jakiego powoływana jest w postępowaniach upadłościowych rada wierzycieli, tj. reprezentacja ogółu wierzycieli.

Niezależnie od podniesionych powyżej przez SN argumentów, już prima facie uznanie za ważną uchwałę rady wierzycieli, która przyjęta została tylko jednym głosem, jednego z pięciu członków rady wierzycieli, wzbudza wewnętrzny sprzeciw co do "poczucia sprawiedliwości” z punktu widzenia każdego człowieka, czemu zapewne dał wyraz także sędzia komisarz kwestionując legalność uchwały, wskutek czego sprawa ostatecznie trafiła na forum SN. Oczywiście pozostaje pytanie: czy i w jak wielu przypadkach była aprobowana przez sądy praktyka podejmowania uchwał przez rady wierzycieli w tak kontrowersyjnym składzie i liczbie oddanych głosów.

Jak była o tym mowa powyżej, jeszcze na tle art. $136 \S 1$ pr.upadł.34 zdania były podzielone $\mathrm{w}$ doktrynie, co do interpretacji tego przepisu, a w szczególności zawartego w nim sformułowania: „uchwały rady wierzycieli zapadają większością głosów". 
Według pierwszego stanowiska, wyrażonego przez J. Korzonka, do powzięcia uchwały rady

wymagana jest zwykła większość głosów, którą oblicza się według głów w stosunku do całej ilości członków rady, a nie w stosunku do liczby członków obecnych na posiedzeniu. Jeżeli więc rada składa się z trzech członków, to uchwała zapada z chwilą, gdy się za nią opowie dwóch członków; jeżeli rada składa się z pięciu członków, to do powzięcia uchwały potrzeba opowiedzenia się co najmniej trzech członków ${ }^{8}$.

Stanowisko J. Korzonka można uznać za dominujące. Opowiedzieli się za nim D. Altman ${ }^{9}$ oraz W. Gawlas i W. Jonsik ${ }^{10}$, a także, jak się wydaje, G. Lauter ${ }^{11}$, który komentując właśnie art. 136 pr.upadł.34 stwierdza, że skład rady został $\mathrm{w}$ ten sposób ustalony, aby uzyskanie większości było zawsze możliwe, gdyż na miejsce członka rady, niemogącego pełnić swych obowiązków osobiście, wchodzi zastępca. Zdanie to pozbawione byłoby sensu, gdyby G. Lauter dopuszczał głosowanie rady w składzie innym niż wyznaczy przez sędziego-komisarza.

Odmienne stanowisko wyraził M. Allerhand, według którego:

nie jest konieczne, aby uchwała zapadła taką większością, jaka odpowiada większości członków rady, jeżeli więc rada składa się z pięciu członków, a na posiedzeniu obecni byli trzej członkowie, to wystarczy większość dwóch członków, a nie jest potrzebna jednomyślność obecnych. Przyjąć to należy, bo zasadą jest, że uwzględnia się tylko głosy obecnych, a pomija się nieobecnych, chyba że ustawa stanowi co innego ${ }^{12}$.

8 J. Korzonek, Prawo upadłościowe i prawo o postępowaniu układowym. Komentarz, Kraków 1935, s. 465.

9 Zob. D. Altman, Prawo upadtościowe. Komentarz, Warszawa 1936, s. 248.

10 Zob. W. Gawlas, W. Jonsik, Prawo upadtościowe wraz z przepisami wprowadzającemi prawo upadtościowe i prawo o postępowaniu układowem z komentarzem uwzględniajacym przepisy kodeksu zobowiązan, wzgl. kodeksu cywilnego obow. na ziemiach zachodnich Rzeczypospolitej Polskiej, kodeksu handlowego oraz przepisy kodeksu postępowania cywilnego, Poznań 1935, s. 151-152.

11 Zob. G. Lauter, Prawo upadłościowe i prawo o postępowaniu układowem. Komentarz, Warszawa 1935, s. 123.

12 Zob. M. Allerhand, Prawo upadłościowe. Komentarz, Bielsko-Biała 1996, s. 272. 
Obowiązujące w okresie międzywojennym ustawodawstwo niemieckie i austriackie, do którego nawiązuje przedwojenna regulacja ${ }^{13}$, normowało zagadnienie następująco. Według § 89 ust. 3 zdanie 3 austriackiej ordynacji insolwencyjnej ${ }^{14}$ "do podjęcia uchwały (decyzji) przez radę wierzycieli (wydział wierzycieli) potrzeba tyle głosów ile odpowiada większości wszystkich członków rady wierzycieli"15. Natomiast według $\S 82$ niemieckiej ordynacji konkursowej ${ }^{16}$, „, uchwała rady wierzycieli (wydziału wierzycieli) jest ważna, gdy większość członków wzięło udział w głosowaniu, a decyzja została podjęta bezwzględną większością głosów oddanych"17. W świetle powyższego, wydaje się, że treść art. 136 $\S 1$ pr.upadł.34 w większym stopniu nawiązuje do treści prawa austriackiego, aczkolwiek pominięto w nim słowo „wszystkich” odnośnie do

13 Podkreślenia wymaga, za uzasadnieniem projektu prawa upadłościowego i naprawczego, że projekt nawiązywał nie tylko do wszystkich ustaw zaborczych obowiązujących na ziemiach polskich, ale także miał na uwadze nowsze ustawodawstwa innych państw i literaturę prawa upadłościowego, zob. Komisja Kodyfikacyjna, Uzasadnienie projektu prawa upadłościowego w opracowaniu Podkomisji Postępowania Upadłościowego na podstawie referatu Prof. M. Allerhanda, Warszawa 1935, s. 5. W doktrynie podnosi się jednak, że polskie prawo upadłościowe zostało opracowane głównie na podstawie prawa niemieckiego i austriackiego, zob. H.G. Landfermann, Najważniejsze problemy reformy niemieckiego prawa o niewypłacalności, [w:] J. Brol (red.), Niemieckie prawo insolwencyjne, tłum. M.A. Zieliński, Warszawa 1996, s. 12.

14 Bundesgesetz über das Insolvenzverfahren vom 10. Dezember 1914, Reichsgesetzblatt für die im Reichsrath vertretenen Königreiche und Länder, Nr 337/1914 (dalej: $\mathrm{IO})$.

15 Zob. § 89 ust. 3 zdanie 3 IO: „Zu einem Beschluß bedarf es so vieler Stimmen, als der Mehrheit aller Mitglieder des Gläubigerausschusses entspricht".

16 Konkursordnung vom 10. Februar 1877, Deutsches Reichsgesetzblatt Band 1877, Nr. 10 Seite 351-389 (dalej: KO).

17 Zob. § 82 KO: „Ein Beschluß des Gläubigerausschusses ist gültig, wenn die Mehrheit der Mitglieder an der Beschlußfassung Theil genommen hat, und der Beschluß mit absoluter Mehrheit der abgegebenen Stimmen gefaßt ist". De lege lata obowiązuje w Niemczech § 72 Insolvenzordnung vom 5. Oktober 1994 (BGBl. I S. 2866), die zuletzt durch Artikel 16 des Gesetzes vom 20. November 2015 (BGBl. I S. 2010) geändert worden ist (dalej: InsO), o następujacym, zbliżonym, brzmieniu: „[Beschlüsse des Gläubigerausschusses] Ein Beschluß des Gläubigerausschusses ist gültig, wenn die Mehrheit der Mitglieder an der Beschlußfassung teilgenommen hat und der Beschluß mit der Mehrheit der abgegebenen Stimmen gefaßt worden ist”. Przepis ten jest tłumaczony: „Uchwała komitetu wierzycieli jest ważna, jeżeli w podejmowaniu uchwały brała udział większość członków i jeżeli uchwała została podjęta większością oddanych głosów", zob. J. Brol (red.), Niemieckie prawo insolwencyjne, tłum. M.A. Zieliński, Warszawa 1996, s. 59-60. 
składu rady wierzycieli. Pominięcie to nie daje jednak moim zdaniem podstawy do wniosku, że $\mathrm{z}$ tego powodu sens normy zawartej w art. 136 $\S 1$ pr.upadł.34 jest jednoznaczny z normą niemiecką, gdzie prawodawca niemiecki wyraźnie unormował, że należy brać pod uwagę większość liczoną podług liczby członków, którzy wzięli udział w głosowaniu.

W okresie powojennym, zdania doktryny dotyczące interpretacji art. $136 \S 1$ pr.upadł.34 nadal są podzielone. Pogląd J. Korzonka aprobują, F. Zedler ${ }^{18}$, P. Pogonowski ${ }^{19}$ oraz J. Rażewski ${ }^{20}$. Zdaniem F. Zedlera, redakcja art. $136 \S 1$ pr.upadł.34 daje podstawę do zajęcia stanowiska, że do podjęcia uchwały konieczna jest większość wszystkich członków rady, natomiast według P. Pogonowskiego, poza powyższym argumentem podniesionym przez F. Zedlera, za poglądem tym przemawia sens i cel działania rady, a nadto konfrontacja treści art. 136 $\S 1$ pr.upadł.34 z art. 148 pr.upadł.34 (obecnie 199 ust. 1 u.p.u.n.03), w którym zagadnienie quorum wyraźnie uregulowano. Pogląd M. Allerhanda reprezentują natomiast S. Gurgul ${ }^{21}$, R. Kowalkowski ${ }^{22}$ oraz K. Piasecki ${ }^{23}$.

Spór jest kontynuowany na tle interpretacji art. 207 ust. 1 u.p.u.n.03, z tym jednak zastrzeżeniem, że na tle tej regulacji, przeważa stanowisko reprezentowane w okresie międzywojennym przez $\mathrm{M}$. Allerhanda - czyli większość oblicza się stosownie do liczby członków rady wierzycieli obecnych na posiedzeniu i bez względu na liczbę przybyłych na posiedzenie członków. Zaznaczyć jednak należy w tym miejscu, że co do kwestii quorum, to zdaniem M. Allerhanda, wystarczy przybycie dwóch członków rady na posiedzenie ${ }^{24}$. Stanowisko takie prezentują R. Adamus ${ }^{25}$, S. Gur-

18 Zob. F. Zedler, Prawo upadtościowe i układowe, Torun 1997, s. 121.

19 Zob. P. Pogonowski, Organy postępowania upadłościowego, Warszawa 2001, s. 248; tenże, Rada wierzycieli w postępowaniu upadłościowym, „Prawo Spółek” 2002, nr 5, s. 53.

20 Zob. J. Rażewski, Prawo upadłościowe. Komentarz praktyczny, Torun 1999, s. 259.

21 Zob. S. Gurgul, Prawo upadłościowe i układowe. Komentarz, Warszawa 2002, s. 508.

${ }^{22}$ Zob. R. Kowalkowski, [w:] B. Jasinkiewicz i in., Prawo upadtościowe i układowe. Komentarz. Wzory pism, Gdańsk 2001, s. 275.

23 Zob. K. Piasecki, Prawo upadtościowe, prawo o postępowaniu układowym, bankowe postępowanie ugodowe wraz z komentarzami oraz ochrona roszczeń pracowniczych, międzynarodowe aspekty upadłości, Bydgoszcz 1994, s. 114.

${ }_{24}$ Zob. M. Allerhand, Prawo upadłościowe..., s. 272. Pogląd ten został wypowiedziany w komentarzu do art. 136 pr.upadł.34.

25 Zob. R. Adamus, Rada wierzycieli w postępowaniu upadłościowym z możliwościa zawarcia układu z zarządem wspólnym, „Monitor Prawniczy” 2006, nr 18, s. 1008. 
gul $^{26}$, D. Zienkiewicz ${ }^{27}$. Charakterystyczne jest, że wymienieni autorzy zasadniczo nie przedstawiają żadnej argumentacji za tym stanowiskiem - odmiennym od argumentacji przytoczonej przez M. Allerhanda.

Stanowisko, że większość głosujących oblicza się w stosunku do liczby członków całej rady aktualnie prezentują A. Pokora ${ }^{28}$, F. Zedler ${ }^{29}$ oraz P. Zimmerman ${ }^{30}$.

Według A. Pokory, najbardziej uzasadniony i jedynie możliwy do przyjęcia, jest pogląd, że do podjęcia uchwały przez radę konieczna jest obecność pełnego jej składu. Za tym stanowiskiem przemawia analogia do przepisów o składzie sądu i skutkach braku właściwego składu w postępowaniu cywilnym rozpoznawczym. Wobec tego autor dochodzi do wniosku, że za każdym razem podjęcie uchwały przez radę w niepełnym składzie prowadzi do nieważności uchwały ${ }^{31}$.

Feliks Zedler podnosi, że za tezą, iż większość oblicza się stosownie do całego składu rady przemawia także wykładnia językowa przepisów prawa upadłościowego i naprawczego, w szczególności treść art. 207 ust. 1 u.p.u.n.03, w którym mowa jest o „uchwałach rady”, a więc uchwałach organu wierzycieli jako całości, a nie o uchwałach obecnych na posiedzeniu członków rady.

Bardzo obszernie pogląd swój uzasadnia P. Zimmerman, według którego za poglądem zgodnym z powyższym przemawia szereg argumentów, z tym że stanowisko tego autora nie w pełni wydaje się konsekwentne, gdyż z jednej strony wyklucza on stanowczo, aby uchwała mogła zapaść głosem jednego wierzyciela, z drugiej jednak ewentualność taką dopuszcza w sytuacji, gdy wszyscy członkowie rady biorą udział w głosowaniu.

26 Zob. S. Gurgul, Prawo upadtościowe. Prawo restrukturyzacyjne. Komentarz, Warszawa 2016, s. 503.

27 Zob. D. Zienkiewicz, [w:] D. Zienkiewicz (red.), Prawo upadtościowe i naprawcze. Komentarz, Warszawa 2006, s. 488.

28 Zob. A. Pokora, Rada wierzycieli w postępowaniu upadłościowym, [w:] J. Wojtyła, A. Witosz (red.), Restrukturyzacja spótek handlowych. Zagadnienia ekonomiczne i prawne, Studia Ekonomiczne - Uniwersytet Ekonomiczny w Katowicach 67, Katowice 2011, s. 143.

29 Zob. F. Zedler, [w:] A. Jakubecki, F. Zedler, Prawo upadtościowe i naprawcze, Warszawa 2010, s. 476.

30 Zob. P. Zimmerman, Prawo upadłościowe. Prawo restrukturyzacyjne. Komentarz, Warszawa 2016, s. 436-437.

31 Argument ten jest moim zdaniem o tyle chybiony, że Kodeks postępowania cywilnego nie zna pojęcia nieważności „orzeczenia” (w tym uchwały), lecz tylko nieważność całego postępowania. 
Po pierwsze, P. Zimmerman stwierdza, że ustawa prawo upadłościowe konsekwentnie przy wszystkich głosowaniach wskazuje, według jakiej podstawy liczyć większość, jeżeli przy radzie nie wskazuje, to oznacza to, że chodzi o większość rady - nie obecnych. Po drugie, że instytucja zastępców członków byłaby zbędna, gdyby nieobecność członka oznaczała po prostu inny stosunek głosów, a nie niemożność podjęcia uchwały. Po trzecie, z faktu, iż ustawa nie mówi o quorum wynika, iż nie ma ono dla liczenia głosów znaczenia, więc większość liczy się nie od przybyłych, a od wszystkich. Po czwarte, konsekwentne przyjęcie drugiego z tych stanowisk doprowadziłoby do wniosku, iż wystarczy głos jedynego przybyłego na posiedzenie rady wierzyciela, aby przegłosować uchwałę. Po piąte, P. Zimmerman podnosi, że zamiar ustawodawcy wskazuje ustanowienie ustawowych, obowiązkowo nieparzystych składów rady wierzycieli. Ostatecznie zatem - niezależnie od liczby obecnych na głosowaniu aby uchwała została przyjęta, „za” muszą być oddane dwa głosy w radzie trzyosobowej, a w radzie pięcioosobowej - trzy głosy. Jeżeli z powodu nieobecności członka nie może on wziąć udziału w głosowaniu, udział bierze jego zastępca, gdy tego brak - uchwała nie może zapaść. Jeżeli jednak wierzyciele są obecni na posiedzeniu rady, ale nie chcą oddać głosu ani "za”, ani „przeciw” (wstrzymują się od głosu), to uchwała rady może zapaść mniejszą liczbą głosów (nawet jedynym oddanym za uchwałą, gdy reszta składu rady wstrzymała się od głosu). Nie ma bowiem wtedy zdaniem cytowanego autora - wątpliwości, że wszystkim członkom rady wierzycieli dano szanse zajęcia stanowiska.

Do grupy autorów reprezentujących powyższy pogląd, jak się wydaje, zaliczyć należy także L. Zielińskiego ${ }^{32}$, którego stanowisko jest jednak rozbudowane i bardzo kazuistyczne. Autor ten podnosi, że rozważania, czy ma to być większość liczona od całej liczby członków rady wierzycieli, czy też większość obecnych na posiedzeniu rady wierzycieli, nie mają praktycznego sensu - z pominięciem sytuacji, w której uznamy, że także jeden członek rady wierzycieli biorący udział w posiedzeniu będzie legitymowany do podejmowania uchwał. Jeżeli bowiem rada wierzycieli liczy trzech członków, to głosów oddanych „za” uchwałą może być trzy lub dwa. W innym przypadku, zdaniem L. Zielińskiego, uchwała nie może być przyjęta. Jeżeli zaś zdarzyłoby się, iż stawi się tylko dwóch członków

32 Zob. L. Zieliński, [w:] A. Witosz, A.J. Witosz (red.), Prawo upadłościowe i naprawcze. Komentarz, Warszawa 2014, s. 521-522. 
(lub pełniących ich funkcje zastępców), to „za” uchwałą, aby mogła zostać przyjęta, muszą być oddane dwa głosy. Gdyby głosy rozłożyły się - nie ma możliwości przyjęcia uchwały. Próg matematyczny jest więc faktycznie taki sam. Jeżeli zaś uchwała rady wierzycieli została podjęta w składzie pięciu członków, to do jej przyjęcia "za” może zostać oddane od pięciu do dwóch głosów. Hipotetycznie więc przy pięcioosobowej radzie wierzycieli i udziału w jej posiedzeniu trzech (przy stosunku głosów 2:1 „za”) lub dwóch członków oddających głosy "za” (czyli de facto „za” jest jedynie dwóch obecnych w stosunku do trzech nieobecnych członków rady wierzycieli, przy założeniu, że pozostali członkowie głosowaliby „przeciw”) powstaje problem sporu co do większości. Jak zaznacza L. Zieliński, jest to problem czysto hipotetyczny - na posiedzeniu bowiem nieobecnych musiałoby być trzech lub czterech członków albo ich zastępców (przy nieobecności pięciu członków lub w ich miejsce zastępców, problem, co oczywiste, w ogóle nie powstaje). Gdyby jednak zaistniała taka sytuacja, to według tego autora uchwała podjęta „większością" tylko dwóch głosów „za” przy pięcioosobowym składzie rady wierzycieli nie powinna być uznana za skuteczną. Należy ponadto dodać, że autor ten zauważa, że wszelkich problemów związanych z interpretacją art. 207 ust. 1 u.p.u.n.03 uniknęła ustawa niemiecka, która w $\S 72$ InsO, co nie jest bezdyskusyjne, gdyż pamiętać należy, że treść zarówno ordynacji konkursowej niemieckiej i ordynacji insolwencyjnej austriackiej - jak zaznaczono powyżej - była znana historycznym kodyfikatorom prawa upadłościowego.

Mimo, że w doktrynie wielu wyżej wymienionych przedstawicieli doktryny odwołuje się do wykładni językowej art. 207 ust. 1 u.p.u.n.03, w szczególności podnosząc, że większość rady, w rozumieniu tego przepisu, oznacza większość jej całego składu wyznaczonego przez sędziego-komisarza, to - mimo iż argument ten jest istotny - nie przesądza jednoznacznie kwestii ustalenia liczby członków obecnych na posiedzeniu niezbędnych do ważności uchwały podejmowanej przez radę wierzycieli.

W tej sytuacji konieczne wydaje się odwołanie do celu i roli rady wierzycieli w systemie polskiego prawa postępowania upadłościowego. Było i nadal jest niekwestionowane twierdzenie, że rada wierzycieli jest jednym z organów postępowania upadłościowego ${ }^{33}$. Należy jednak zauważyć, że

33 Zob. J. Korzonek, Prawo upadłościowe..., s. 467; P. Pogonowski, Rada wierzycieli..., s. 53; D. Zienkiewicz, [w:] D. Zienkiewicz (red.), Prawo upadłościowe..., s. 474; P. Zimmerman, Prawo upadłościowe..., s. 416. 
organ ten jest uregulowany w systemie ustawy Prawo upadłościowe i naprawcze w rozdziale 2 („Wierzyciele”) w dziale III (,Uczestnicy postępowania”), który występuje obok działów II („Syndyk i zastępca syndyka”) i I („Sąd i sędzia-komisarz”). Prima facie zatem można wysnuć wniosek, że jest to wyłącznie organ wierzycieli (wierzycielski). Istnieją jednak kardynalne różnice między zgromadzeniem wierzycieli a radą wierzycieli. Różnice te podniesiono już w projekcie uzasadnienia historycznego projektu prawa upadłościowego, stwierdzając, że polskie prawo nie recypuje rozwiązań obcych ${ }^{34}$, gdzie organem, który wraz z syndykiem współdziała $\mathrm{w}$ interesie wierzycieli w zarządzaniu masą upadłości, jest wydział lub rada wierzycieli. Jednak projekt, nie uznając autonomii wierzycieli, zajmuje inne stanowisko, a mianowicie decyzję pozostawia sądowi, a konkretnie pozostawia kontrolę syndyka sędziemu kierującemu postępowaniem (tj. sędziemu-komisarzowi) ${ }^{35}$. Podkreśla się jednocześnie, że stanowisko projektu nie jest skrajne, umożliwia bowiem sędziemu-komisarzowi zasadniczo fakultatywne powołanie rady wierzycieli ${ }^{36}$.

Mając na uwadze powyższe, podzielić należy w całej rozciągłości pogląd O. Bubera, że prawo polskie odejmuje radzie wierzycieli prawie całkowicie charakter, który właściwie rada mieć powinna, a mianowicie charakter organu ogółu wierzycieli, a nadaje jej raczej charakter sędziego-komisarza, ułatwiając temu kontrolę nad syndykiem i odciążając go od jego własnych obowiązków nadzorczych ${ }^{37}$. Stanowisko swoje O. Buber uzasadnia przytaczając przepisy prawa upadłościowego, którym odpowiadają następujące przepisy zawarte w: art. 152 § 1 u.p.u.n.03 (wskazanie czynności, których wykonywanie przez syndyka jest niedopuszczalne bez zezwolenia sędziego-komisarza lub bez zezwolenia rady wierzycieli); art. 201 § 1 i 202 § 1 u.p.u.n.03 (powołanie i odwołanie członków rady wierzycieli przez sędziego-komisarza); art. 213 § 1 i 2 u.p.u.n.03 (wykonywanie kompetencji rady przez sędziego-komisarza). Piotr Pogonowski uznaje stanowisko O. Bubera za znacznie upraszczające charakter rady, jednakże i ten autor przytacza niemal in extenso wypowiedź i argumentację

${ }^{34}$ Oswald Buber podaje przykłady wypaczeń instytucji rady wierzycieli $\mathrm{w}$ prawie niemieckim i austriackim, w tym przytacza (za E. Jaegerem), że osoby, które uczyniły sobie zawód z członkostwa w radzie „hyjenami konkursowymi”, zob. O. Buber, Polskie prawo upadtościowe, Warszawa 1936, s. 105.

35 Zob. Komisja Kodyfikacyjna, Uzasadnienie projektu prawa upadłościowego..., s. 83.

36 Zob. tamże.

37 Zob. O. Buber, Polskie prawo upadtościowe, s. 106. 
O. Bubera, konstatując za nim, że wszystkie uprawnienia rady (w przypadku jej ustanowienia) są także pochodną statusu sędziego-komisarza w postępowaniu ${ }^{38}$.

Przyjmując zatem za zasadne stanowisko, że rada wierzycieli jest organem postępowania upadłościowego o charakterze publicznoprawnym, mającym za zadanie reprezentować nie tylko interes poszczególnych członków rady (czego nie da się uniknąć w pełni ${ }^{39}$ ), lecz kierować się przede wszystkim treścią prawa i reprezentować interes ogółu wierzycieli ${ }^{40}$, wykluczyć należy wszelkie analogie do przepisów regulujących zgromadzenie wierzycieli, $w$ tym przepisy o sposobie głosowania i quorum $w$ trakcie głosowania przez zgromadzenie wierzycieli (art. 198-199 u.p.u.n.03). Jednocześnie powyższe stanowisko skłania do spojrzenia na radę wierzycieli jako na organ dublujący - w określonym zakresie - kompetencje sędziego-komisarza i z tego oczywistego powodu, bardziej zasadne w zakresie sposobu procedowania, wydają się poszukiwanie podobieństwa do ustrojowej i ustawowej roli sędziego-komisarza niż zgromadzenia poszczególnych wierzycieli.

W związku z tym uznać należy, że skład rady wierzycieli wyznacza ustawa i konkretne postanowienie sędziego-komisarza (art. 201 § 1 i art. 202 § 1 u.p.u.n.03). Ustawa w zakresie decyzyjnym rady (podejmowania uchwał) zna tylko pełny skład organu, podobnie jak w przypadku procesów decyzyjnych innych sądowych organów postępowania upadłościowego (np. art. 150 u.p.u.n.03 dotyczący składu sądu w postępowaniu upadłościowym), czy szerzej organów postępowania cywilnego, a brak wyraźnych regulacji ustawowych nie pozwala konstruować inne, pozaustawowe składy obradujące kolegialnie. Nie powinna pozostawiać najmniejszej wątpliwości teza, że uchwała podjęta w składzie nieznanym ustawie, przykładowo w składzie siedmiu

38 Zob. P. Pogonowski, Organy postępowania upadłościowego, s. 250-251.

$39 \mathrm{~W}$ doktrynie podnosi się tylko, że mimo braku przepisu przedstawiciel rady wierzycieli nie powinien głosować nad uchwałą dotyczącą jego interesu prawnego, lecz w tych wyjątkowych sytuacjach być zastąpiony przez zastępcę, zob. M. Allerhand, Prawo upadłościowe..., s. 281; S. Gurgul, Prawo upadłościowe. Prawo restrukturyzacyjne. Komentarz, Warszawa 2016, s. 504. Stanowisko to wyrażone przez M. Allerhanda, moim zdaniem zarazem pośrednio wyklucza możliwość wstrzymania się od oddania głosu bez ważnej podstawy faktycznej przez członka rady wierzycieli.

40 Zob. uzasadnienie uchwały Sądu Najwyższego z dnia 21 kwietnia 2016 r., III CZP 3/16. 
członków rady wierzycieli (np. w składzie pięciu członków i dwóch zastępców) podlegać będzie uchyleniu przez sędziego-komisarza w trybie art. 210 u.p.u.n.03 i vice versa - że w tym samym trybie powinna zostać uchylona uchwała podjęta $w$ niepełnym składzie, jak i każde orzeczenie sądu wydane w postępowaniu cywilnym w składzie sprzecznym z przepisami prawa procesowego - oczywiście, o ile zostanie we właściwym trybie zaskarżone. Dodatkowo, dostrzegając większe podobieństwo w zakresie roli i zadań rady wierzycieli do sędziego-komisarza, nie wydaje się możliwe, aby ustawa przyznawała któremukolwiek z członków rady wierzycieli (pomijając wspomniany wcześniej przypadek oczywistego i jaskrawego konfliktu interesów) możliwość czy też uprawnienie do niepodejmowania decyzji. Co do zasady, niedopuszczalne jest zatem zarówno niepodejmowanie decyzji przez radę kolegialnie, jak i jej poszczególnych członków, czemu ustawodawca, moim zdaniem, daje wyraz brakiem regulacji ustawowej dopuszczenia możliwości zaniechania w podejmowaniu decyzji poprzez nieusprawiedliwione nieprzybycie członka na posiedzenie rady lub przyznając mu expressis verbis prawo wstrzymania się przez niego od głosowania ${ }^{41}$. Należy postawić pytanie: czy uprawnienia takie przysługują sędziemu-komisarzowi oraz sędziom (lub ławnikom) orzekającym w składach kolegialnych? Moim zdaniem, mając na uwadze zasadę legalizmu (tj. działania organów sądowych i procesowych) tylko w granicach zakreślonych przez prawo ${ }^{42}$, $\mathrm{z}$ milczenia ustawodawcy $\mathrm{w}$ przepisach regulujących tryb głosowania w radzie wierzycieli, co do możliwości „wstrzymania się od głosu” przez członka rady, nie powinno się wywodzić wniosku, że ustawa przyznaje członkom rady wierzycieli możliwość „wstrzymania się od głosu" nad uchwałą. Uprawnienia takiego nie można absolutnie wywodzić $\mathrm{z}$ analogii z art. 198 § 1 u.p.u.n.03, gdzie wierzyciel głosując nad uchwałą reprezentuje wyłącznie swój, autonomiczny,

${ }^{41}$ Jak się wydaje argumentu za stanowiskiem przeciwnym nie dostarcza art. 212 ust. 2 u.p.u.n.03, który stanowi, że sędzia-komisarz wykonuje ponadto czynności zastrzeżone dla rady wierzycieli, jeżeli rada nie wykona ich w terminie wyznaczonym przez sędziego-komisarza. Niewykonanie czynności przez radę może bowiem wynikać zarówno z okoliczności niezawinionych przez członków rady (sytuacje losowe), jak i zawinionych (świadome nieprzybycie członka na posiedzenie, złożenie rezygnacji), wobec czego przepis powyższy służy zapewnieniu sprawności postępowania upadłościowego bez względu na przyczynę niepodjęcia czynności przez radę.

42 Zob. art. 7 Konstytucji Rzeczypospolitej Polskiej z dnia 2 kwietnia 1997 r., Dz. U. z 1997 r. Nr 78, poz. 483 z późn. zm. 
interes prawny odnośnie do jego własnych cywilnoprawnych praw podmiotowych. Jak wiadomo, podstawową cechą tych praw jest to, że pozostawione są one autonomii i swobodnej dyspozycji uczestników obrotu cywilnoprawnego $\mathrm{w}$ zakresie ich realizacji ( $\mathrm{w}$ tym $\mathrm{w}$ kwestii ich dochodzenia $\mathrm{w}$ postępowaniu cywilnym lub upadłościowym). Zupełnie inna jest natomiast rola publicznoprawnych organów procesowych (sędziego, a nawet ławników), które nie mają swobody, lecz obowiązek określonego działania $\mathrm{w}$ zakresie podejmowania publicznoprawnych czynności procesowych organu, którego skład stanowią. Moim zdaniem podniesione wyżej argumenty powinny przemawiać za poglądem, że członkowie rady wierzycieli mają obowiązek udziału w posiedzeniach rady i głosowania na jej posiedzeniu ${ }^{43}$. Poza już podniesionymi argumentami, o istnieniu tego rodzaju obowiązku wnioskować należy z treści art. 212 u.p.u.n.03, który stanowi, że członek rady wierzycieli odpowiada za szkodę wynikłą z nienależytego pełnienia obowiązków ${ }^{44}$. Tym bardziej członek odpowiadał będzie za niewypełnianie swoich obowiązków. Wydaje się, że argumentu do poglądu przeciwnego, a mianowicie, że udział członków w radzie nie jest obowiązkowy na posiedzeniach rady, nie można wywodzić z treści art. $209 \S 1$ u.p.u.n.03: "Z posiedzenia rady wierzycieli spisuje się protokół, który podpisują obecni. Odmowę złożenia podpisu zaznacza się w protokole". Przepis ten nie dotyczy bowiem kwestii quorum głosujących ani tym bardziej wykazywać istnienia uprawnienia do absencji na posiedzeniu rady lub uprawnienia do wstrzymania się od głosowania, lecz - przepis ten dla celów dowodowych - przewiduje obowiązek podpisania protokołu przez wszystkich obecnych na posiedzeniu rady, których może być więcej niż członków rady uprawnionych do głosowania (art. 208 u.p.u.n.03) ${ }^{45}$. Stanowisko, o wyłącznie dowodowym charakterze podpisów „wszystkich obecnych” znajduje moim zdaniem potwierdzenie $\mathrm{w}$ tym, że niemal identyczną normę o podobnym ratio legis zawiera

43 Oswald Buber wypowiedział się, że: „Opinjodawcze zadanie rady wierzycieli wobec syndyka polega na obowiązku rozpatrywania spraw i wydawaniu opinji o nich, na zebraniach rady, zwołanych przez syndyka", tenże, Polskie prawo upadłościowe, s. 109.

44 Zdaniem I. Gil, z art. 212 u.p.u.n.03 wynika, że odpowiedzialność członków rady wierzycieli jest zbliżona do odpowiedzialności odszkodowawczej syndyka i zarządcy, zob. I. Gil, [w:] A. Hrycaj, A. Jakubecki, A. Witosz (red.), Prawo restrukturyzacyjne i upadłościowe, System Prawa Handlowego 6, Warszawa 2016, s. 940.

45 Każdorazowo zresztą bez prawa głosu powinni stawić się zastępcy, którzy nagle mogą uzyskać prawo do głosowania, np. przy zasłabnięciu któregoś z członków rady. 
art. 809 pkt 6 Kodeksu postępowania cywilnego ${ }^{46}$, a który stanowi, że protokół sporządzony przez komornika powinien zawierać podpisy obecnych lub wzmiankę o przyczynie braku podpisu.

\section{Wnioski}

Reasumując przeprowadzone rozważania, na aprobatę zasługuje stanowisko zawarte w uchwale SN z dnia 21 kwietnia 2016 r., że na tle art. 207 ust. 1 u.p.u.n.03, uchwały rady wierzycieli zapadają zawsze większością głosów członków wyznaczonego składu rady, przy czym większość tę (tj. dwa lub trzy głosy „za”) oblicza się w stosunku do ogółu członków rady (tj. trzech lub pięciu członków). W uzasadnianiu tej tezy zawarto jednak sformułowanie, że z treści art. 207 ust. 1 u.p.u.n.03 nie wynika, by do podjęcia uchwały konieczne było oddanie głosów przez wszystkich członków rady wierzycieli. Z konstatacji tej w pierwszej kolejności płyną dwa wnioski, a mianowicie, że w ocenie SN do ważności uchwały podjętej przez radę wierzycieli na posiedzeniu nie jest potrzebna obecność wszystkich członków rady wierzycieli, a nadto, że mimo obecności wszystkich członków, niektórzy z nich mogą "nie brać udziału w głosowaniu”, co w mojej ocenie należy uznać za przyzwolenie do „wstrzymania się" przez obecnych od oddania głosu „za” lub „przeciw” projektowi uchwały. Jednocześnie twierdzenie, że do podjęcia uchwały wymagana jest większość wynosząca dwa lub trzy głosy obliczone w stosunku do ogółu członków rady, determinuje pogląd, że wymagane quorum, czyli wymagana minimalna liczba obecnych na posiedzeniu rady członków, wynosi odpowiednio dwóch lub trzech członków.

Stanowisko powyższe jest niewątpliwie wyrazem zastosowania funkcjonalnej metody wykładni i znajdzie aprobatę w praktyce. W świetle podniesionych powyżej uwag, wydaje się jednak, że systemowe i celowościowe metody wykładni odwołujące się do roli rady wierzycieli mogą prowadzić do odmiennego wniosku, a mianowicie, że na tle art. 207 ust. 1 u.p.u.n.03, do podjęcia uchwały wymagana jest zasadniczo obecność wszystkich powołanych przez sędziego-komisarza członków

46 Ustawa z dnia 17 listopada 1964 r. - Kodeks postępowania cywilnego, tekst jednolity: Dz. U. z 2019 r. poz. 1460 z późn. zm. 
rady, z tym, że $\mathrm{w}$ miejsce nieobecnego członka rady głosuje zastępca. W przypadku braku obecności wszystkich członków rady, czyli w przypadku braku pełnego składu rady (mimo przystąpienia do głosowania zastępców w miejsce nieobecnych), uchwała nie może zostać skutecznie podjęta, a w przypadku jej podjęcia w niepełnym składzie, podlega uchyleniu z urzędu przez sędziego-komisarza, który jednocześnie podejmuje decyzję za radę $w$ trybie art. 213 ust. 2 u.p.u.n.03.

Tego rodzaju stanowisko powinno korelować z poglądem, że ustawa Prawo upadłościowe i naprawcze nie przewiduje prawa do wstrzymania się od głosowania przez członka rady wierzycieli (lubjego zastępcę). Niestety, mimo podniesionych wcześniej istotnych argumentów wywiedzionych z językowych i systemowych dyrektyw wykładni, oddanie tego rodzaju głosów na posiedzeniu rady wierzycieli należy jednak dopuścić, gdyż przy założeniu prawidłowości poglądu o obowiązkowej obecności wszystkich członków rady wierzycieli na posiedzeniu - wstrzymanie się od głosu przez któregokolwiek z członków rady, oznaczałoby, że osoba taka de facto odmawia udziału w czynnościach rady, a więc powinna być potraktowana jak osoba nieuczestnicząca $w$ głosowaniu. W ten sposób dochodzimy jednak do wniosku interpretacyjnego ad absurdum, że jeden z członków rady wierzycieli swoim zachowaniem $\mathrm{w}$ trakcie głosowania uzyskuje sui generis indywidualne prawo weta do projektu głosowanej uchwały, gdyż brak udziału przez niego w głosowaniu prowadziłby do nieważności uchwały. Zatem ostatecznie należy uznać, że trafne są wypowiedzi doktryny ${ }^{47}$ dopuszczające oddanie głosów „wstrzymujących się” w głosowaniu przez członków rady wierzycieli na tle art. 207 ust. 1 u.p.u.n.03, aczkolwiek de lege ferenda postulować należy wyraźne uregulowanie tej kwestii w obecnie obowiązującej ustawie prawa upadłościowego, w szczególności mając na uwadze wyraźny ustawowy wymóg „oddania głosów przez wszystkich członków rady wierzycieli" sformułowany w treści normy prawnej zawartej w art. 207 ust. 1a u.p.u.n.03.

Słowa kluczowe: postępowanie upadłościowe, organy postępowania upadłościowego, rada wierzycieli w postępowaniu upadłościowym, skład rady wierzycieli, głosowanie $\mathrm{w}$ radzie wierzycieli

47 Zob. G. Lauter, Prawo upadłościowe..., s. 248; K. Piasecki, Prawo upadłościowe..., s. 114, z tym że wypowiedź tego autora dotyczy członka głosującego in rea sua; L. Zieliński, [w:] A. Witosz, A.J. Witosz (red.), Prawo upadłościowe..., s. 521-522; P. Zimmerman, Prawo upadtościowe..., s. 437. 


\section{Bibliografia}

Adamus R., Rada wierzycieli w postępowaniu upadłościowym z możliwościa zawarcia układu z zarządem wspólnym, „Monitor Prawniczy” 2006, nr 18.

Allerhand M., Prawo upadłościowe. Komentarz, Bielsko-Biała 1996.

Altman D., Prawo upadłościowe. Komentarz, Warszawa 1936.

Buber O., Polskie prawo upadłościowe, Warszawa 1936.

Gawlas W., W. Jonsik, Prawo upadłościowe wraz z przepisami wprowadzajacemi prawo upadłościowe i prawo o postępowaniu układowem z komentarzem uwzględniajacym przepisy kodeksu zobowiązań, wzgl. kodeksu cywilnego obow. na ziemiach zachodnich Rzeczypospolitej Polskiej, kodeksu handlowego oraz przepisy kodeksu postępowania cywilnego, Poznań 1935.

Gil I., [w:] A. Hrycaj, A. Jakubecki, A. Witosz (red.), Prawo restrukturyzacyjne i upadłościowe, System Prawa Handlowego 6, Warszawa 2016.

Gurgul S., Prawo upadłościowe i układowe. Komentarz, Warszawa 2002.

Gurgul S., Prawo upadłościowe. Prawo restrukturyzacyjne. Komentarz, Warszawa 2016.

Hrycaj A., B. Groele, [w:] A. Hrycaj, P. Filipiak (red.), Prawo restrukturyzacyjne. Komentarz, Warszawa 2017.

Korzonek J., Prawo upadłościowe i prawo o postępowaniu układowym. Komentarz, Kraków 1935.

Kowalkowski R., [w:] B. Jasinkiewicz i in., Prawo upadłościowe i układowe. Komentarz. Wzory pism, Gdańsk 2001.

Landfermann H.G., Najważniejsze problemy reformy niemieckiego prawa o niewyptacalności, [w:] J. Brol (red.), Niemieckie prawo insolwencyjne, tłum. M.A. Zieliński, Warszawa 1996.

Lauter G., Prawo upadłościowe i prawo o postepowaniu układowem. Komentarz, Warszawa 1935.

Piasecki K., Prawo upadłościowe, prawo o postępowaniu układowym, bankowe postepowanie ugodowe wraz z komentarzami oraz ochrona roszczeń pracowniczych, międzynarodowe aspekty upadłości, Bydgoszcz 1994.

Pogonowski P., Organy postępowania upadłościowego, Warszawa 2001.

Pogonowski P., Rada wierzycieli w postępowaniu upadłościowym, "Prawo Spółek” 2002, nr 5.

Pokora A., Rada wierzycieli w postępowaniu upadłościowym, [w:] J. Wojtyła, A. Witosz (red.), Restrukturyzacja spółek handlowych. Zagadnienia ekonomiczne i prawne, Studia Ekonomiczne - Uniwersytet Ekonomiczny w Katowicach 67, Katowice 2011.

Rażewski J., Prawo upadłościowe. Komentarz praktyczny, Toruń 1999. 
Komisja Kodyfikacyjna, Uzasadnienie projektu prawa upadłościowego w opracowaniu Podkomisji Postępowania Upadtościowego na podstawie referatu Prof. M. Allerhanda, Warszawa 1935.

Zedler F., Prawo upadłościowe i układowe, Toruń 1997.

Zedler F., [w:] A. Jakubecki, F. Zedler, Prawo upadłościowe i naprawcze, Warszawa 2010.

Zieliński L., [w:] A. Witosz, A.J. Witosz (red.), Prawo upadłościowe i naprawcze. Komentarz, Warszawa 2014.

Zienkiewicz D., [w:] D. Zienkiewicz (red.), Prawo upadtościowe i naprawcze. Komentarz, Warszawa 2006.

P. Zimmerman, Prawo upadtościowe. Prawo restrukturyzacyjne. Komentarz, Warszawa 2016.

\section{CALCULATION OF THE MAJORITY OF VOTES REQUIRED TO PASS A RESOLUTION OF THE CREDITORS' COMMITTEE IN BANKRUPTCY PROCEEDINGS. REMARKS CONCERNING THE RESOLUTION OF THE SUPREME COURT OF APRIL 21, 2016, III CZP 3/16}

\section{Summary}

A direct impulse for these considerations is the resolution of the Polish Supreme Court of 21 April 2016 (III CZP 3/16), which provides the answer to two legal questions concerning the issue of calculating the majority of votes in the creditors' committee in the bankruptcy proceedings.Discussing the problems noticed in the judicature, the author refers to the statements of the Polish doctrine, in which the dispute began in the interwar period and was not unambiguously settled (until the above mentioned resolution) in the views of contemporary representatives of the juridical doctrine. The core of the problem concerns the question whether and how the majority of votes is calculated in the case of absence of some members at a meeting of creditors' committee, and when the members at the meeting of the creditors' committee cast 'abstentions', i.e. they do not take an unequivocal position either "for" or "against" the resolution.In conclusion, the author states that resolutions of the creditors' committee are always adopted by a majority of members of the designated composition of the council, the majority being calculated in relation to all council members (i.e. three or five) and with the required presence of all council members appointed by the judge-commissioner.

Key words: bankruptcy proceedings, bodies in bankruptcy proceedings, the creditors' committee in bankruptcy proceedings, the composition of the creditors' committee, voting at the creditors' committee meeting 


\section{ПОДСЧЕТ БОЛЬШИНСТВА ГОЛОСОВ, НЕОБХОДИМОГО ДЛЯ ПРИНЯТИЯ РЕШЕНИЯ СОВЕТОМ КРЕДИТОРОВ ПРИ ПРОВЕДЕНИИ ПРОЦЕДУРЫ БАНКРОТСТВА. КОММЕНТАРИИ ОТНОСИТЕЛЬНО ПОСТАНОВЛЕНИЯ ВЕРХОВНОГО СУДА ОТ 21 АПРЕЛЯ 2016 ГОДА, III CZР 3/16}

\section{Резюме}

Непосредственным импульсом внедряемых решений является постановление Верховного суда от 21 апреля 2016 г. (III CZP 3/16), в котором дается ответ на два юридических вопроса, касающихся чрезвычайно важных для практики вопросов подсчета большинства голосов в совете кредиторов при проведении процедуры банкротства. Автор обсуждает проблемы, выявленные в судопроизводстве, анализируя положения польской доктрины, в которой спор обозначился еще в межвоенный период, и не был до принятия вышеупомянутого решения однозначно разрешен во взглядах современных представителей доктрины. Суть проблемы касается вопроса о том, подсчитывается ли и каким образом большинство голосов в случае отсутствия некоторых членов совета на заседании, или в том случае, если присутствующие на заседании совета кредиторов члены „воздерживаются”, то есть, не занимают однозначную позицию „за” или „против” решения. В заключение автор констатирует, что решение совета кредиторов всегда принимаются большинством голосов членов определенного состава совета, при этом большинство рассчитывается по отношению к общему числу членов совета (то есть, три или пять), и при требуемом присутствии всех назначенных судьей-комиссаром членов совета.

Ключевые слова: процедура банкротства, органы, занимающиеся процедурой банкротства, совет кредиторов при проведении процедуры банкротства, состав совета кредиторов, голосование в совете кредиторов 
